\title{
Penggunaan CONUT Score sebagai Prediktor Komplikasi Pasca Pem- bedahan Kanker Kolorektal di RSUP Prof. Dr. R. D. Kandou Manado
}

\author{
${ }^{1}$ Hendry Sundah, ${ }^{2}$ Toar Mambu, ${ }^{2}$ Ferdinand Tjandra, ${ }^{2}$ Heber B. Sapan, ${ }^{2}$ Winfrid M. \\ Sumanti
}

\author{
${ }^{1}$ PPDS Ilmu Bedah Fakultas Kedokteran Universitas Sam Ratulangi Manado \\ ${ }^{2}$ Divisi Bedah Digestif Bagian Ilmu Bedah Universitas Sam Ratulangi/RSUP Prof. Dr. R. D. \\ Kandou Manado \\ Email: h3nry_jhn@yahoo.com
}

\begin{abstract}
Nutritional status is one of the factors that influence the metabolic and physiological conditions. Cancer patients, especially colorectal cancer (CRCA), will suffer from decreased nutritional status during their sickness. CONUT score is beneficial to evaluate the nutritional and immunity status of the patients and has been proved to correlate with post operative complications and length of stay. This study was aimed to evaluate the relationship between CONUT score and postoperative complications in CRCA patients. This was an analytical observational study with a cross sectional design. Subjects were 38 patients of CRCA that underwent operation and were admitted at Surgery Inpatients Installation of Prof. Dr. R. D. Kandou Hospital Manado. The result of logistic regression analysis indicated that there was a significant correlation between CONUT score and the risk of complication. The higher the CONUT score, the higher the risk of complication. The determination of complication diagnostic value based on CONUT score was obtained by using ROC curve. The ROC analysis showed that the AUC of CONUT score was $0.977>0.700$ and the cutoff point of CONUT score was 5.5. Patients with CONUT score $\geq 5.50$ had a tendency to get postoperative complications with the sensitivity of $86.6 \%$, specifity of $95.6 \%$, and accuracy of 94.74\%. Conclusion: CONUT score can be used as a screening method to predict the occurence of postoperative complications in CRCA patients.
\end{abstract}

Kata kunci: colorectal cancer, CONUT score, postoperative complications

\begin{abstract}
Abstrak: Salah satu faktor yang memengaruhi keadaan metabolik dan fisiologik ialah status nutrisi. Penderita kanker terlebih kanker kolorektal (KKR) akan mengalami pengurangan nutrisi selama perjalanan penyakit. CONUT score bermanfaat untuk mengevaluasi status gizi dan imunitas pasien serta terbukti berkolerasi dengan komplikasi serta jumlah hari rawat di rumah sakit pasca pembedahan. Penelitian ini bertujuan untuk mengetahui hubungan CONUT score dengan komplikasi pasca pembedahan KKR. Jenis penelitian ialah analitik observasional dengan desain potong lintang. Subyek penelitian ialah 38 pasien KKR yang menjalani operasi dirawat di Instalasi Rawat Inap Bedah RSUP Prof. Dr. R. D. Kandou Manado. Hasil analisis regresi logistik menyatakan terdapat hubungan yang sangat bermakna antara CONUT score dan kejadian komplikasi. Hubungan ini menyatakan bahwa makin tinggi CONUT score makin besar risiko terjadinya komplikasi. Penentuan nilai diagnostik komplikasi berdasarkan CONUT score diperoleh melalui kurva ROC. Berdasarkan analisis ROC diperoleh AUC CONUT score 0,977 >0,700. Hasil analisis ROC memperoleh titik potong CONUT score $=5,5$. Pasien dengan CONUT score $\geq 5,50$ memiliki kecenderungan mengalami komplikasi dengan sensitivitas $86,6 \%$, spesifitas $95,6 \%$, dan nilai akurasi $94,74 \%$. Simpulan: CONUT score dapat digunakan sebagai metode skrining untuk memrediksi terjadinya komplikasi pasca pembedahan kanker kolorektal.
\end{abstract}

Kata kunci: karsinoma kolorektal (KKR), CONUT score, komplikasi pasca pembedahan 
Penanganan pembedahan memerlukan suatu keadaan metabolik dan fisiologik yang seimbang untuk mempertahankan fungsi jaringan dan organ. Salah satu faktor yang memengaruhi hal ini ialah status nutrisi. Malnutrisi menyebabkan pengurangan massa otot, perubahan mekanisme pernafasan, gangguan fungsi kekebalan tubuh, dan atrofi intestinal. Perubahan ini memperlambat penyembuhan luka, predisposisi terhadap infeksi, peningkatan morbiditas pasca pembedahan, dan memanjangnya waktu perawatan di rumah sakit. ${ }^{1}$ Kanker kolorektal (KKR) merupakan kanker ganas yang dijumpai pada kolon dan rektum. Penyakit ini mempunyai angka morbiditas dan mortalitas yang tinggi dan tersebar di berbagai negara di dunia. Kanker kolorektal merupakan keganasan keempat terbanyak di dunia dan penyebab kematian kedua terbanyak di Amerika Serikat. $^{2}$ Berdasarkan data dari World Cancer Research Fund International (WCRF) tahun 2012 KKR menempati peringkat ketiga setelah kanker paru dan kanker payudara sebagai kanker dengan frekuensi terbanyak dengan 1,4 juta kasus baru. $^{3}$

Angka kejadian kanker kolorektal telah banyak dilaporkan di Indonesia. Dari data Globocan 2012, insiden kanker kolorektal di Indonesia ialah 12,8 per 100.000 penduduk usia dewasa, dengan mortalitas 9,5\% dari seluruh kasus kanker. Di Indonesia, kanker kolorektal sekarang menempati urutan nomor 3 (Globocan 2012), dengan kenaikan tajam yang diakibatkan oleh perubahan diet pada orang Indonesia, baik sebagai konsekuensi peningkatan kemakmuran serta pergeseran ke arah cara makan orang Barat (westernisasi) yang lebih tinggi lemak serta rendah serat. ${ }^{4}$

Semua pasien kanker akan mengalami pengurangan nutrisi dan penurunan berat badan pada suatu saat selama perjalanan penyakit. Pada pasien kanker kolorektal masalah tersebut akan sangat berpengaruh karena tumor terletak di saluran cerna sehingga sering memberikan gejala berupa obstruksi dan diare yang menyebabkan gangguan penyerapan nutrisi. Dukungan nutrisi telah menjadi tambahan penting dalam merawat pasien kanker namun hingga saat ini belum ada penilaian status nutrisi yang memuaskan. ${ }^{1}$

Penilaian status nutrisi merupakan proses untuk mengidentifikasi penderita yang mengalami malnutrisi maupun yang berisiko berkembang menjadi malnutrisi. Hingga saat ini banyak penelitian tentang status nutrisi salah satunya CONUT score, yang sangat mudah dihitung berdasarkan nilai serum albumin, jumlah limfosit, dan kolesterol total yang telah dilaporkan berguna untuk mengevaluasi status gizi dan imunitas pasien serta terbukti berkolerasi dengan komplikasi serta jumlah hari rawat di rumah sakit pasca pembedahan.

\section{METODE PENELITIAN}

Penelitian ini bertujuan untuk untuk mengetahui hubungan antara CONUT Score dengan komplikasi pasca-pembedahan kanker kolorektal di RSUP Prof. Dr. R. D. Kandou Manado. Jenis penelitian ini ialah analitik observasional bentuk korelasional dengan desain potong lintang.

Hubungan antara CONUT Score dengan kadar albumin, limfosit, dan kolesterol total diuji dengan analisis regresi dan korelasi Pearson. Penentuan nilai diagnosis komplikasi berdasarkan CONUT score diperoleh melalui kurva ROC.

\section{HASIL PENELITIAN}

Penelitian ini dilakukan di Instalasi Rawat Inap Bedah RSUP Prof. Dr. R. D. Kandou Manado dari bulan Oktober 2017 sampai dengan bulan Mei 2018. Pada penelitian ini terdapat 38 pasien kanker kolorektal yang menjalani operasi, terdiri dari 23 orang laki-laki $(60,5 \%)$ dan 15 orang perempuan $(39,5 \%)$, dengan distribusi usia terbanyak pada dekade kelima dan keenam (Gambar 1).

Sebelum dilakukan operasi, diambil sampel darah pasien untuk diperiksa kadar albumin, kolesterol, dan kadar limfositnya kemudian dihitung CONUT score. Pasien diamati selama 30 hari pasca pembedahan atau sampai meninggal dunia. 


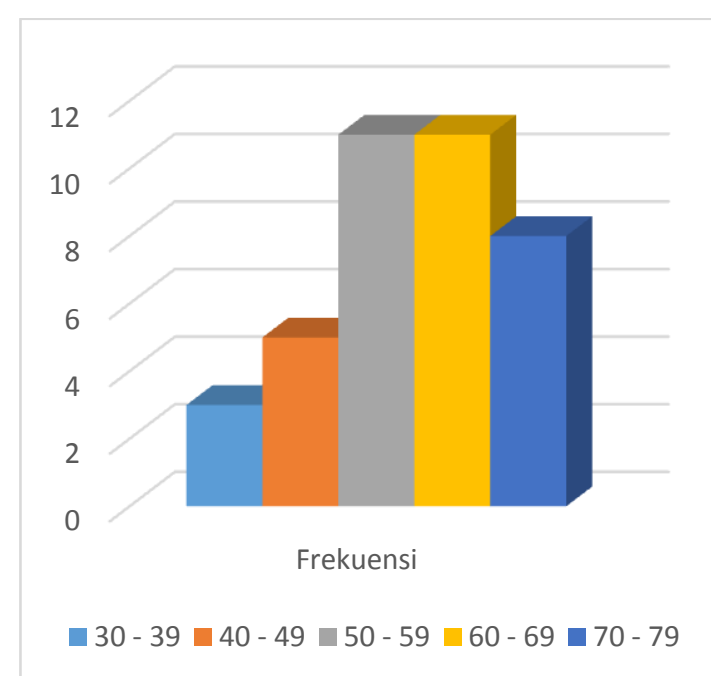

Gambar 1. Distribusi usia pasien KKR

Rerata usia pasien yang mengalami komplikasi lebih tinggi daripada rerata usia yang tidak mengalami komplikasi yaitu 60,5 tahun (SD $\pm 9,54$ tahun) berbanding 57,1 tahun ( $\mathrm{SD} \pm 12,59$ tahun) (Tabel 1).
Sebaran pasien KKR berdasarkan jenis kelamin dan komplikasi memperlihatkan dari 38 pasien didapatkan 23 orang tidak mengalami komplikasi, terdiri dari 14 orang $(60,9 \%)$ laki-laki dan 9 orang $(39,1 \%)$ perempuan. Pasien yang mengalami komplikasi terdiri dari 9 orang $(60,0 \%)$ laki-laki dan 6 orang $(40.0 \%)$ perempuan (Tabel 2).

Tabel 1. Nilai statistik usia berdasarkan komplikasi

\begin{tabular}{lcc}
\hline \multirow{2}{*}{ Nilai statistik usia } & \multicolumn{2}{c}{ Komplikasi } \\
& Ya & Tidak \\
\hline Rerata (tahun) & 60,4 & 57,1 \\
Simpangan baku & 9,54 & 12,59 \\
(tahun) & & \\
Minimum (tahun) & 42 & 32 \\
Maksimum (tahun) & 75 & 77 \\
\hline
\end{tabular}

Tabel 2. Distribusi pasien berdasarkan jenis kelamin dan komplikasi

\begin{tabular}{lccc}
\hline \multirow{2}{*}{ Jenis kelamin } & \multicolumn{2}{c}{ Komplikasi } & \multirow{2}{*}{ Total } \\
& Ya & Tidak & \\
\hline Laki-laki & $9(60,0 \%)$ & $14(60,9 \%)$ & $23(60,5 \%)$ \\
Perempuan & $6(40,0 \%)$ & $9(39,1 \%)$ & $15(39,5 \%)$ \\
Total & $15(100,0 \%)$ & $23(100,0 \%)$ & $38(100,0 \%)$ \\
\hline
\end{tabular}

Hubungan antara CONUT score dengan albumin, limfosit, dan kolestrol total diuji dengan analisis regresi dan korelasi Pearson. Gambar 2 memperlihatkan bahwa terdapat hubungan bermakna antara CONUT score dengan kadar albumin. Makin tinggi CONUT score makin rendah kadar albumin $(\mathrm{r}=-0,738$ dengan nilai $P<0,01)$.

Gambar 3 menunjukkan terdapat hubungan bermakna antara CONUT score dengan kadar limfosit. Makin tinggi CONUT score makin rendah kadar limfosit ( $\mathrm{r}=-0,476$ dengan nilai $P<0,01)$.

Gambar 4 menunjukkan terdapat hubungan bermakna antara CONUT score dengan kadar kolesterol total. Makin tinggi CONUT score makin rendah kadar kolesterol total $(\mathrm{r}=-0,588$ dengan nilai $P<0,01)$.

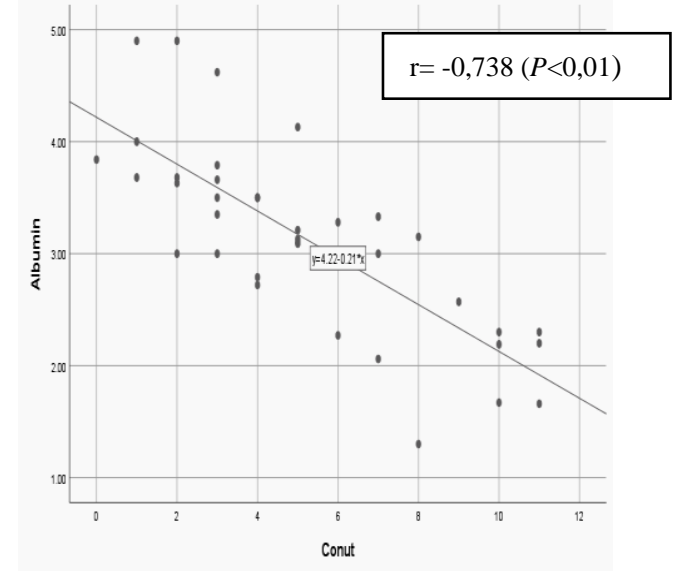

Gambar 2. Diagram pencar hubungan CONUT score dengan kadar albumin

Hasil analisis regresi logistik yang terdapat pada tabel diatas menyatakan terdapat hubungan bermakna antara CONUT score dan kejadian komplikasi, 


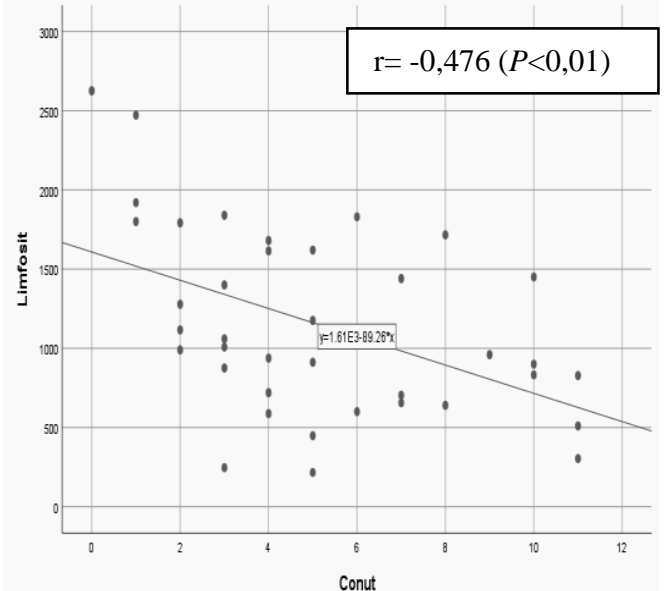

Gambar 3. Diagram pencar hubungan CONUT score dengan kadar limfosit

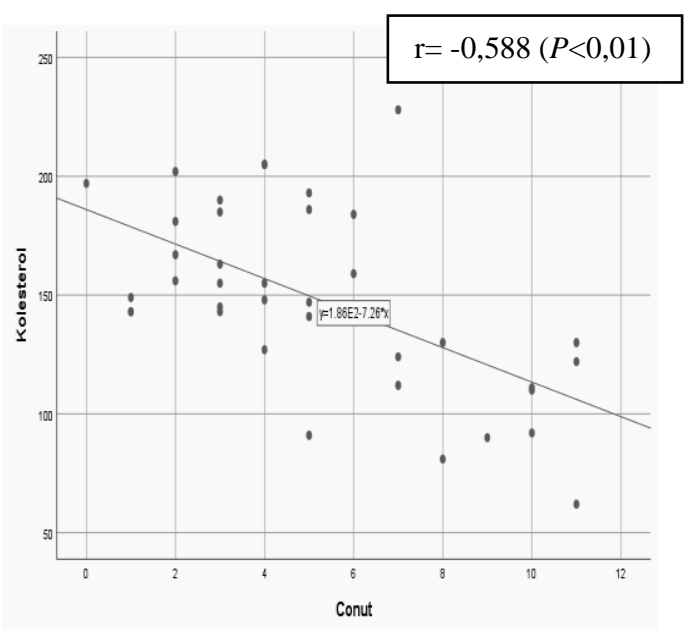

Gambar 4. Diagram pencar hubungan CONUT score dengan kolesterol total

dan dapat digunakan sebagai prediktor komplikasi, sebab nilai Sig. $(P)=0,020$ $<0,05$. Hubungan ini menyatakan bahwa makin tinggi CONUT score makin besar peluang terjadinya komplikasi.

Berdasarkan analisis ROC diperoleh AUC CONUT score ialah 0,977 >0,700. Hasil ini menunjukkan penentuan nilai diagnosis komplikasi berdasarkan CONUT score dapat digunakan. Hasil analisis ROC memperoleh titik potong CONUT score $=$ 5,5. Berdasarkan titik potong CONUT score 5,5 diperoleh nilai diagnostik sebagai berikut (Tabel 3). Hasil penghitungan mendapatkan sensitivitas sebesar 86,6\%, spesifisitas $95,6 \%$, nilai prediksi positif $92,8 \%$, nilai prediksi negatif $91,7 \%$, dan akurasi 94,74\%.

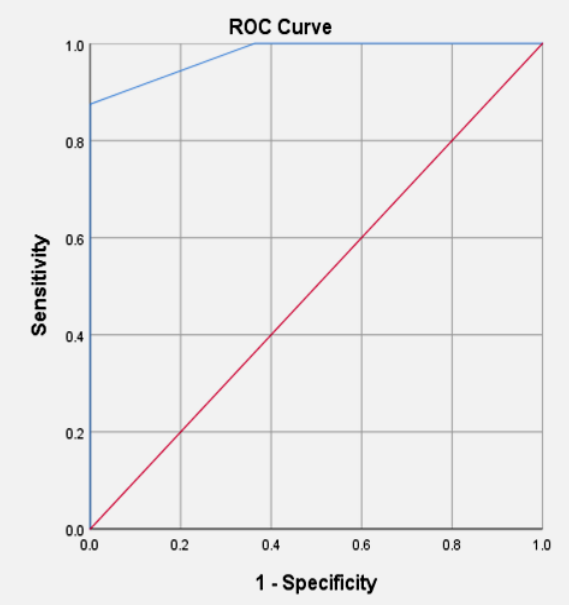

Gambar 5. Kurva ROC sebagai penentu area under the curve (AUC)

Tabel 3. Klasifikasi pasien berdasarkan komplikasi dan titik potong CONUT score

\begin{tabular}{cccc}
\hline & \multicolumn{3}{c}{ Komplikasi } \\
CONUT & Ya & Tidak & Total \\
Score & & & \\
\hline$\geq 5,50$ & 13 & 1 & 14 \\
$<5,50$ & 2 & 22 & 24 \\
Total & 15 & 23 & 38 \\
\hline
\end{tabular}

\section{BAHASAN}

Malnutrisi merupakan kondisi yang sering terjadi pada penderita KKR dan merupakan faktor prognostik independen untuk peningkatan risiko komplikasi pasca pembedahan, mengurangi respon terhadap pengobatan antikanker, dan menyebabkan kelangsungan hidup lebih pendek. Kanker kolorektal sering menyebabkan gejala berupa obstruksi usus atau diare yang sangat memengaruhi penyerapan nutrisi di usus. Oleh karena itu diagnosis dini malnutrisi sangat penting untuk menurunkan morbiditas dan mortalitas pasca pembedahan. Namun, di banyak pusat kanker, penilaian nutrisi praoperasi tidak rutin dilakukan karena keterbatasan baik ketersediaan ahli nutrisi atau kurangnya protokol. CONUT score ialah skor evaluasi gizi yang sangat mudah dihitung dari serum albumin, total kolesterol, dan jumlah limfosit. CONUT score telah dilaporkan bermanfaat untuk mengevaluasi status gizi dan imunitas pasien. $^{5}$

Distribusi penderita KKR berdasarkan 
usia memperlihatkan bahwa yang paling banyak terdeteksi ialah pada dekade kelima dan keenam (Gambar 1). Rentang usia 5059 tahun dan 60-69 tahun masing-masing sebanyak 11 orang $(28,9 \%)$ terdeteksi KKR. Walaupun KKR paling banyak ditemukan pada dekade ke-5 dan ke-6, keganasan ini juga didapatkan pada usia muda. Pada usia 70 tahun ke atas insidens KKR cenderung menurun; hal ini mungkin disebabkan karena angka kelangsungan hidup yang juga cenderung rendah di Indonesia. Lebih dari $90 \%$ KKR terjadi pada yang berusia 50 tahun atau lebih tua dibandingkan yang lebih muda dari 40 tahun. $^{6}$

Hasil penelitian mendapatkan bahwa berdasarkan jenis kelamin didapatkan sebanyak 23 orang laki-laki dan 15 orang perempuan yang menderita KKR (Tabel 2). Perbandingan laki-laki dan perempuan yang menderita KKR mendekati angka 2:1 yang berarti laki-laki hampir 2 kali lebih banyak menderita dibanding perempuan. Hal ini dapat disebabkan karena laki-laki lebih sering terpapar dengan faktor risiko dibanding perempuan.

Hubungan antara CONUT score dengan kadar albumin, limfosit, dan kolesterol total diuji dengan korelasi Pearson. Terdapat hubungan bermakna antara CONUT score dengan kadar albumin yaitu makin tinggi CONUT score makin rendah kadar albumin $(P<0,01)$, dengan komplikasi yang terjadi semakin tinggi (Gambar 2). Albumin serum memiliki angka dua kali dibandingkan dengan parameter lainnya. Skor tersebut diberikan sesuai dengan pengalaman yang diperoleh; Albumin memberi lebih banyak nilai 2 kali lebih dibandingkan dengan parameter lain. ${ }^{5}$ Konsentrasi albumin serum dipengaruhi oleh status gizi dan juga oleh banyak faktor lain, seperti kerusakan hepatosit, infeksi, peradangan, dehidrasi, status retensi cairan, dll. ${ }^{7,8}$ Prognosis yang lebih buruk dari penderita KKR dengan konsentrasi albumin yang lebih rendah dikaitkan adanya peradangan kronis dan sistemik. ${ }^{5}$

Terdapat hubungan bermakna antara CONUT score dengan kadar limfosit, yaitu makin tinggi CONUT score makin rendah kadar limfosit $(P<0,01)$, dan komplikasi yang terjadi semakin tinggi. Jumlah limfosit perifer total ialah salah satu indikator status imunologi. Limfosit $\mathrm{T}$ berperan penting dalam respon imun terhadap kanker. ${ }^{9}$ Menges et al $^{10}$ menyatakan bahwa limfopenia yang disebabkan oleh respon inflamasi sistemik ditandai dengan depresi yang signifikan dari imunitas seluler bawaan, yang ditunjukkan oleh penurunan tajam limfosit T-helper dan NK-cell (natural killer cell). Penurunan Tlimfosit dilaporkan berkorelasi dengan prognosis buruk karena respon imun yang tidak memadai terhadap kanker. ${ }^{9}$

Terdapat hubungan bermakna antara CONUT score dengan kadar kolesterol total. Makin tinggi CONUT score makin rendah kadar kolesterol total $(P<0,01)$, sehingga komplikasi yang terjadi semakin tinggi. Kadar kolesterol serum yang rendah dilaporkan berhubungan dengan prognosis yang lebih buruk pada pasien dengan berbagai kanker. Meskipun masih belum jelas mengapa kadar kolesterol serum rendah dikaitkan dengan prognosis yang buruk, hipokolesterolemia tidak dianggap sebagai penyebab kanker tetapi diinduksi oleh kanker. Terdapat peningkatan ekspresi mRNA reseptor LDL di jaringan tumor dibandingkan jaringan normal. Ekspresi reseptor LDL pada sel tumor membuat selsel ini mengambil banyak LDL yang menurunkan kadar kolesterol serum. ${ }^{11}$ Hipokolesterolemia memengaruhi fluiditas membran sel, yang memengaruhi mobilitas reseptor permukaan sel dan kemampuannya untuk mentransmisikan sinyal transmembran. Oleh karena itu, bahkan jika terdapat jumlah cukup sel imunokompeten, sel-sel tersebut tidak dapat menggunakan fungsi imunologinya terhadap sel-sel kanker karena perubahan dalam membrannya. ${ }^{12}$

Pada penelitian ini, dari 38 pasien KKR didapatkan 15 orang mengalami komplikasi, yaitu infeksi luka operasi pada 6 pasien, kebocoran anastomosis 1 pasien, dan meninggal dunia sebanyak 8 pasien. Pada penelitian yang dilakukan oleh Saito et $\mathrm{al}^{13}$ komplikasi yang terjadi pasca pembedahan berupa abses intra-abdomen, 
sepsis, ileus, pneumoni, kebocoran anastomosis, dan kematian yang terjadi pada 9 dari 52 pasien yang menjalani operasi.

Hasil pengujian hubungan CONUT score dan kejadian komplikasi dilakukan menggunakan analisis regresi logistik dengan program SPSS versi 25 menyatakan terdapat hubungan yang sangat bermakna antara CONUT score dan kejadian komplikasi, serta dapat digunakan sebagai prediktor komplikasi karena nilai Sig. $(P)=0,020$ $<0,05$. Hubungan ini menyatakan bahwa makin tinggi CONUT score makin besar risiko terjadinya komplikasi.

Penentuan nilai diagnosis komplikasi berdasarkan CONUT score diperoleh melalui kurva ROC sebagai penentu area under the curve (AUC). Berdasarkan analisis ROC diperoleh AUC CONUT score ialah $0,977>0,700$. Hasil ini menunjukkan penentuan nilai diagnosis komplikasi berdasarkan CONUT score dapat digunakan. Hasil analisis ROC memperoleh titik potong CONUT score $=5,5$. Hal ini sesuai dengan penelitian yang dilakukan oleh Saito et $\mathrm{al}^{13}$ di Jepang yang mendapatkan titik potong 5 (tingkat malnutrisi sedang). Hal ini mungkin disebabkan oleh adanya kesamaan ras Asia. Pada Tabel 3 diperlihatkan bahwa pasien dengan CONUT score $\geq 5,50$ memiliki kecenderungan mengalami komplikasi dengan sensitivitas $86,6 \%$, spesifitas $95,6 \%$. Hal ini juga sesuai dengan penelitian oleh de Ulibarri et $\mathrm{al}^{14}$ yang mendapatkan sensitivitas $(92,30 \%)$ dan spesifisitas (85\%) yang cukup tinggi sehingga CONUT score dapat digunakan sebagai metode skrining yang valid untuk deteksi dini malnutrisi di rumah sakit.

\section{SIMPULAN}

Berdasarkan hasil penelitian ini dapat disimpulkan bahwa CONUT score dapat digunakan sebagai metode skrining untuk memrediksi terjadinya komplikasi pasca pembedahan kanker kolorektal. Titik potong CONUT score sebagai penentu komplikasi yang diperoleh pada penelitian ialah 5,5 dengan nilai sensitivitas $86,6 \%$ nilai spesifitas $95,6 \%$, dan nilai akurasi $94,74 \%$.

\section{DAFTAR PUSTAKA}

1. Shary TM, Chapman EA, Hermann VA. Surgical metabolism \& nutrition In: Doherty G, editor. Current Surgical Diagnosis \& Treatment (14th ed). Boston: McGraw Hill, 2015; p. 117-20.

2. Siegel RL, Miller KD, Jemal A. Cancer statistics, 2016. CA Cancer J Clin. 2016;66:7-30.

3. Ferlay J, Soerjomataram I, Ervik M, Dikshit R, Eser S, Mathers C, et al. GLOBOCAN 2012 v1.1, Cancer incidence and mortality worldwide: IARC Cancer Base No. 11. Lyon, France: International Agency for Research on Cancer, 2014.

4. Basir I, Rudiman R, Lusikoy R, Syafei I, Lukman $K$, Abdullah $M$, et al. Panduan Penatalaksanaan Kanker Kolorektal. Jakarta: Perhimpunan Dokter Spesialis Bedah Digestif Indonesia, 2014; p. 1-64.

5. Tokunaga R, Sakamoto $Y$, Nakagawa $S$, Ohuchi M, Izumi D, Kosumi K, et al. CONUT: a novel independent predicttive score for colorectal cancer patients undergoing potentially curative resection. Int J Colorectal Dis. 2016; 32(1):99-106.

6. Haggar FA, Boushey RP. Colorectal cancer epidemiology: Incidence, mortality, survival, and risk factors. Department of Surgery, the Ottawa Hospital Research Institute, 2009; p. 193.

7. Cengiz O, Kocer B, Surmeli S, Santicky MJ, Soran A. Are pretreatment serum albumin and cholesterol levels prognostic tools in patients with colorectal carcinoma? Med Sci Monit. 2006;12(6):240-7.

8. Sonoda A, Ohnishi S, Nakao S, Iwashita Y, Hashimoto N, Ishida K, et al. Factors affecting serum albumin in the perioperative period of colorectal surgery: a retrospective study. BMC Res Notes. 2015;8:638.

9. Liang L, Zhu J, Jia H, Huang L, Li D, Li Q, et al. Predictive value of pretreatment lymphocyte count in stage II colorectal cancer and in high-risk patients treated with adjuvant chemotherapy. Oncotarget. 2016;7(1):1014-28.

10. Menges T, Engel J, Welters I, Wagner RM, Little S, Ruwoldt $R$, et al. Changes in blood lymphocyte popu- 
lations after multiple trauma: association with posttraumatic complications. Crit Care Med. 1999;27(4):73340.

11. Okuyama H, Ichikawa Y, Sun Y, Hamazaki T, Lands WE. Cancer and all-cause mortalities are lower in the higher total cholesterol groups among general populations. World Rev Nutr Diet. 2007;96:37-54.

12. Notarnicola M, Altomare DF, Correale M, Ruggieri E, D'Attoma B, Mastrosimini A, et al. Serum lipid profile in colorectal cancer patients with and without synchronous distant metas- tases. Oncology 2005; 68(4-6):371-4.

13. Saito A, Murakami $M$, Watanabe $M$, Ozawa Y, Tomioka K, Komoto M, et al. Controlling nutritional status is useful for predicting postoperative complications in very elderly patients with colorectal cancer: A retrospective study. Showa Univ J Med Sci. 2016; 28(4):317-25.

14. de Ulíbarri JI, González-Madroño A, de Villar NG, Gonzales P, Gonzales B, Mancha A, at al. CONUT: A tool for controlling nutritional status. First validation in a hospital population. Nutr Hosp. 2005;20(1):38-45. 